\title{
Associations between epidermal thionin-positive cells and skin parasitic infections in brown trout Salmo trutta
}

\author{
Jens Sigh, Kurt Buchmann* \\ Department of Veterinary Microbiology, Section of Fish Diseases, Royal Veterinary and Agricultural University, 4 Stigbøjlen, \\ 1870 Frederiksberg C, Denmark
}

\begin{abstract}
The dynamics of the densities of epidermal thionin-positive cells (putative mast cells) in the skin of brown trout fry were investigated during experimental infections with the skin parasites Ichthyophthirius multifilis (Ciliophora) and Gyrodactylus derjavini (Monogenea). It was shown that the metachromatic thionin-stained cells were extremely sensitive to parasite exposure, as the density of cells in the skin of trout decreased markedly after exposure to the pathogens. As early as $7 \mathrm{~d}$ post infection the cell counts were significantly reduced and almost totally depleted following $9 \mathrm{~d}$ infection, which suggests that degranulation of the cells occurs following parasite exposure. No recruitment of new cells was seen during the study period. Some reduction in uninfected control groups indicates that the putative mast cells are sensitive to stress as well. A notable variation in densities of thionin-stained cells between different fins was found and the corneal surface was devoid of these cells. The possible implications of these cells in host-parasite interactions are suggested and discussed
\end{abstract}

KEY WORDS: Mast cells - Parasites - Trout - Salmo trutta - Host response - Ichthyophthirius multifiliis . Gyrodactylus derjavini

\section{INTRODUCTION}

The structure and function of mast cells in mammals have been extensively studied (Galli et al. 1999) and similar cell types have been described from a range of teleosts. These fish cells have been characterized based on their metachromatic staining with thionin (Reite 1998). However, the function of these cells in fish is still poorly understood. In mammals mast cells are believed to play a major role in both specific and non-specific reactions against foreign substances but whether or not the thionin-positive cells in fish play a similar role is unknown. Besides being important effector cells in allergies (hay fever, asthma, anaphylaxis), the mast cells participate actively in mammalian immune responses to parasites (Harrison et al. 1999). In addition, there is reason to believe that mast cells in mammals have a function in innate immunity to vari-

•Corresponding author. E-mail: kurt.buchmann@vetmi.kvl.dk ous pathogens (Galli et al. 1999). An investigation of how partly corresponding cells in teleosts interact with parasites is therefore relevant.

It is known that teleosts are fully capable of mounting a specific immune response against the ciliate Ichthyophthirius multifiliis (Clark \& Dickerson 1997) and additionally, non-specific reactions in the fish seem to be activated upon infection with this parasite (Buchmann et al. 1999). Likewise, both specific and non-specific systems play a role in the response of teleosts against monogeneans, and several effector mechanisms including mast cells have been suggested to be involved (Buchmann 1999). However, the only indirect suggestion of mast cell involvement in trout associated with ectoparasitic infections was provided by Blackstock \& Pickering (1980). They showed that eosinophilic granular cells were abundant in brown trout epidermis infected with the ectoparasitic flagellate Ichthyobodo necator. Such cells are presumably related to thionin-positive cells. Because they contain cytoplasmic granules with sulphated glycosaminogly- 
cans, they stain metachromatically with basic aniline dyes such as thionin (Reite 1998). As these substances are water soluble, it is necessary to preserve material for staining in absolute alcohol before processing. However, tissue fixed in water soluble fixatives lose this staining ability and appear as eosinophilic granular cells (Reite 1998) as only their acidophilic and water-insoluble granula are retained. Working with alcohol-fixed rainbow trout intestine infected with the acanthocephalan Acanthocephalus dirus, Bullock (1963) found basophilia connected with an epithelial reaction around the parasite's hooks. This could indicate the involvement of basophils or mast cells in the host response. Clearly, the association between tissue mast cell densities and parasitic infections in fish needs to be investigated further.

The present paper elucidates the question of whether any change in metachromatic thionin-positive epidermal cells (putative mast cells) occurs following exposure of brown trout fry to the skin parasitizing parasites Ichthyophthirius multifiliis and Gyrodactylus derjavini.

\section{MATERIALS AND METHODS}

Fish. Uninfected fry of brown trout Salmo trutta were purchased from the Esrom trout hatchery (North Zealand, Denmark) and acclimatized for $7 \mathrm{~d}$ in a thermostat regulated laboratory room $\left(11.6^{\circ} \mathrm{C}\right)$ in aerated municipial water $\left(\mathrm{pH} 7.4, \mathrm{CaCO}_{3} 390 \mathrm{mg} \mathrm{l}^{-1}\right)$ in $200 \mathrm{l}$ aquaria. The fry had a mean body length of $24.8 \mathrm{~mm}$ (SD 1.75) and a mean body weight of $153.7 \mathrm{mg}$ (SD 1.75) $(n=10)$.

\section{Parasites. Ichthyophthirius multifiliis:}

A laboratory stock of this ciliate was established by transferring trophonts from infected rainbow trout obtained from a Danish trout farm (Refsgaard II, Jutland) to uninfected rainbow trout in the laboratory aquaria. After infection the parasite stock was maintained by introduction of naïve fish every few weeks. The laboratory stock was used 8 mo after establishment. Infective theronts were produced from trophonts escaping dissected infected fins of rainbow trout in glass beakers with water. Following tomocyst development and tomite formation, escaping theronts were isolated and counted using a dissecting microscope $(40 \times$ magnification).

Gyrodactylus derjavini: A stock of this monogenean was established in the laboratory based on infected farm trout (Pœele- bro, Jutland) and maintained in $200 \mathrm{l}$ aquaria with live rainbow trout with regular supplement of uninfected fish. The age of the laboratory stock was 3 yr when used.

Experimental procedure. The 2 separate experiments with the 2 parasite species were conducted at $11.6^{\circ} \mathrm{C}$ with a $12 \mathrm{~h}$ light: $12 \mathrm{~h}$ dark cycle. For each experiment 2 aquaria (experimental and control), each containing $4 \mathrm{l}$ aerated water and 40 fish (total volume 17 l) with daily water exchange, were used. Before starting the infection procedure 10 fish were sampled from each aquarium (0 group).

Infection procedure: Infection with Ichthyophthirius multifiliis was produced by exposing 30 fish to infective theronts $\left(40 \mathrm{fish}^{-1}\right)$ for $24 \mathrm{~h}$. Infection with Gyrodactylus derjavin was accomplished by placing dissected fins with attached parasites in the aquaria (160 parasites to $30 \mathrm{fish})(24 \mathrm{~h})$. Infection success with gyrodactylids was monitored after $24 \mathrm{~h}$ or $5 \mathrm{~d}$ by anaesthetizing (MS $22250 \mathrm{mg} \mathrm{l}^{-1}$ ) fry (in a beaker with $50 \mathrm{ml}$ solution) and subsequently counting the number of attached gyrodactylids or ich-parasites, respectively, with a dissecting microscope ( 6 to $40 \times$ magnification). Fish were not touched during this procedure. Infection success with $I$. multifiliis was first recorded after fixation/staining and during the subsequent counting of putative mast cells (see below).

Sampling: Following infection, fish were kept for a total of $9 \mathrm{~d}$. Samples from the various groups, each comprising 10 fish, were taken on Days 0,7 and 9 .

Effect of anaesthesia: In order to clarify whether anaesthesia had any effect on the density of thioninpositive cells 2 groups of trout fry in 17 l aquaria were

Table 1 Gyrodactylus derjavini infecting Salmo trutta. Densities of thioninpositive cells [number of cells field ${ }^{-1}$ i mean and (SD)] in various fins and corneae from brown trout before and after infection ( 7 and 9 d) ( 1 to 3 parasites $\mathrm{fish}^{-1}$ ). Field area $=0.31 \mathrm{~mm}^{2}$ In each group 10 fish were counted. In each fish 3 fields were counted in 2 pectoral fins, 2 pelvic fins, anal fin, caudal fin, adipose fin, dorsal fin, and 2 corneae. $\because p<0.01$ in relation to Day $0, \#: p<0.01$ in relation to uninfected control same day

\begin{tabular}{|lccccccc|}
\hline & $\begin{array}{c}\text { Pectoral } \\
\text { fin }\end{array}$ & $\begin{array}{c}\text { Pelvic } \\
\text { fin }\end{array}$ & $\begin{array}{c}\text { Anal } \\
\text { fin }\end{array}$ & $\begin{array}{c}\text { Caudal } \\
\text { fin }\end{array}$ & $\begin{array}{c}\text { Adipose } \\
\text { fin }\end{array}$ & $\begin{array}{c}\text { Dorsal } \\
\text { fin }\end{array}$ & Cornea \\
\hline Day 0 & 11.1 & 8.5 & 4.5 & 3.1 & 7.8 & 8.2 & 0.0 \\
Uninfected & $(8.1)$ & $(6.3)$ & $(4.5)$ & $(4.4)$ & $(9.4)$ & $(5.5)$ & \\
Day 7 & 6.1 & 5.3 & 7.5 & 2.5 & 6.0 & 3.7 & 0.0 \\
Uninfected & $(7.2)$ & $(3.8)$ & $(11.8)$ & $(2.4)$ & $(7.5)$ & $(2.7)$ & \\
Day 7 & 1.3 & 2.3 & 0.5 & 0.3 & 0.8 & 0.9 & 0.0 \\
Infected & $(1.8)^{*} \#$ & $(3.5)^{*} \#$ & $(0.8)^{\bullet} \#$ & $(0.6)^{*} \#$ & $(2.1)^{*} \#$ & $(2.1)^{*} \#$ & \\
Day 9 & 3.3 & 3.5 & 1.5 & 3.1 & 1.9 & 1.8 & 0.0 \\
Uninfected & $(3.8)$ & $(3.8)$ & $(1.4)$ & $(4.2)$ & $(2.4)$ & $(2.3)$ & \\
Day 9 & 0.2 & 0.2 & 0.2 & 0. & 0.32 & 0.7 & 0.0 \\
Infected & $(0.4)^{\circ} \#$ & $(0.6)^{\circ} \#$ & $(0.5)^{*} \#$ & $(0.5)^{*} \#$ & $(0.6)^{*} \#$ & $(1.2)^{*}$ & \\
\hline
\end{tabular}


used. One group (13 fish) was treated for $5 \mathrm{~min}$ (maximum counting time) in $50 \mathrm{mg} \mathrm{l}^{-1} \mathrm{MS} \mathrm{222,}$ whereas the other group (12 fish) was left untreated. Following $24 \mathrm{~h}$ in pure water, both groups were fixed and processed for cell counting as described below.

Fixation and staining: The sampled fish were preserved in absolute ethanol for more than $2 \mathrm{wk}$. Fins and corneae were then dissected with microscissors, stained with $0.1 \%$ thionin in absolute ethanol $(\mathrm{pH} 4)$, rinsed in absolute ethanol and finally mounted in Depex. Swim bladders from rainbow trout were likewise fixed and stained in order to determine whether the staining of mast cells corresponded to the description provided by Reite \& Evensen (1994).

Mast cell counting: At least 3 zones of $0.31 \mathrm{~mm}^{2}$ were counted on each fin if possible. All cells containing metachromatically stained cytoplasmic granules were registered using a compound microscope (400 $\times$ magnification).

Statistics. For each group of fish the mean number (and SD) of mast cells per counting zone in each fin type was calculated. As the data did not fit a normal distribution the Mann-Whitney $U$-test was used to evaluate differences of means between experimental groups.

\section{RESULTS}

All parasite-exposed fish became infected. Fish exposed to gyrodactylids harboured 1 to 3 parasites per fish after $24 \mathrm{~h}$ and $5 \mathrm{~d}$. Fish exposed to theronts showed visible trophonts in the fins on Days 7 and 9 (recorded in thionin-stained preparations made for mast cell counting).

Metachromatically stained cells in the trout fins were located superficially and showed red cytoplasmic granules despite the deep-blue colour of the primary thionin stain. The density of these cells varied considerably between fins. Thus, uninfected trout showed a high number of cells on the pectoral, pelvic, dorsal and adipose fins, a lower density on the anal and caudal fins and no mast cells in the cornea (Tables $1 \& 2$ ). Following 7 and $9 \mathrm{~d}$ infection with Ichthyophthirius multifiliis and Gyrodactylus derjavini, respectively, a marked and highly significant decrease of the density of thionin-positive cells was observed. In some controls a less notable decrease was seen. However, this was probably not caused by the anaesthesia (MS 222-bath) because no effects of MS 222 could be detected in an associated experiment (Table 3). In addition, the infected fins also contained significantly fewer cells than the corresponding controls sampled at the same time.
Table 2. Ichthyophthirius multifilis infecting Salmo trutta. Densities of thionin-positive cells [number of cells field ${ }^{-1}$; mean and (SD)] in various fins and corneae from brown trout before and after infection ( 7 and $9 \mathrm{~d}$ ). Field area $=0.31 \mathrm{~mm}^{2}$. In each group 10 fish were counted. In each fish 3 fields were counted in 2 pectoral fins, 2 pelvic fins, anal fin, caudal fin, adipose fin, and dorsal fin. $\cdot p<0.01$ in relation to Day $0, \#: p<0.01$ in relation to uninfected control same day

\begin{tabular}{|lcccccc|}
\hline & $\begin{array}{c}\text { Pectoral } \\
\text { fin }\end{array}$ & $\begin{array}{c}\text { Pelvic } \\
\text { fin }\end{array}$ & $\begin{array}{c}\text { Anal } \\
\text { fin }\end{array}$ & $\begin{array}{c}\text { Caudal } \\
\text { fin }\end{array}$ & $\begin{array}{c}\text { Adipose } \\
\text { fin }\end{array}$ & $\begin{array}{c}\text { Dorsal } \\
\text { fin }\end{array}$ \\
\hline Day 0 & 19.7 & 25.5 & 19.9 & 3.7 & 10.1 & 9.9 \\
Uninfected & $(15.5)$ & $(14.4)$ & $(19.3)$ & $(5.8)$ & $(15.5)$ & $(9.3)$ \\
Day 7 & 16.8 & 9.5 & 16.0 & 5.0 & 12.8 & 6.7 \\
Uninfected & $(16.6)$ & $(12.2)$ & $(13.6)$ & $(8.7)$ & $(20.8)$ & $(10.5)$ \\
Day 7 & 1.3 & 0.6 & $(0.4)$ & 0.4 & 0.6 & 1.1 \\
Infected & $(1.9)^{*} \#$ & $(1.0)^{*} \#$ & $(0.9)^{*} \#$ & $(0.9)^{\bullet} \#$ & $(1.5)^{\bullet} \#$ & $(2.5)^{*}$ \\
Day 9 & 15.4 & 14.2 & 15.7 & 6.3 & 13.4 & 14.0 \\
Uninfected & $(9.9)$ & $(13.9)$ & $(16.7)$ & $(10.3)$ & $(14.2)$ & $(14.9)$ \\
Day 9 & 0.1 & 0.2 & 0.2 & 0.1 & 0.3 & 0.1 \\
Infected & $(0.3)^{*} \#$ & $(0.5)^{*} \#$ & $(0.5)^{*} \#$ & $(0.2)^{*} \#$ & $(0.7)^{*} \#$ & $(0.2)^{*} \#$ \\
\hline
\end{tabular}

Table 3. Salmo trutta. Densities of thionin-positive cells [number of cells field ${ }^{-1}$; mean and (SD)] in various fins and corneae from brown trout treated or not treated with MS 222 for 5 min and fixed $24 \mathrm{~h}$ following exposure. Field area $=0.31 \mathrm{~mm}^{2}$ Nos. of fish were 12 and 13 , respectively. No significant difference between groups

\begin{tabular}{|lccc|}
\hline & Pectoral fin & Caudal fin & Dorsal fin \\
\hline Untreated $(\mathrm{n}=12)$ & $5.6(3.6)$ & $1.4(1.5)$ & $5.2(3.3)$ \\
Treated $(\mathrm{n}=13)$ & $5.3(5.5)$ & $1.7(0.3)$ & $5.3(4.9)$ \\
\hline
\end{tabular}

\section{DISCUSSION}

The method used in the present investigation, applying whole-mounts of fry fins, provides a possibility for enumerating thionin-positive cells in the epidermis of fish fins. The cells appear with clear red cytoplasmic granules on an unstained or a slightly bluish background. Thus, this staining method can be used when studying the effect of various physical, chemical and biological factors on these cells. The exact nature of these cells is not clear but due to the metachromatic staining with thionin following fixation in absolute ethanol they fit the description of teleost mast cells provided by Reite (1998). Morphologically they corresponded to the swim bladder mast cells described by Reite \& Evensen (1994) and to similarly stained cells seen by control staining of rainbow trout swim bladder performed by the present authors (data not shown). The function of these putative mast cells in the trout fin are unknown. However, it is noteworthy that the density of these cells shows a fast and marked decrease 
within $7 \mathrm{~d}$ post-infection. Therefore, the possibility cannot be excluded that they have a function in the host response against foreign substances and organisms like parasites. As the non-infected control group experienced a slight decrease in cell density during the experimental period, there are indications that factors other than parasites could play a role. The anaesthetic MS 222 showed no effect on cell density and the fish in the experimental groups were treated in exactly the same way (no manipulation with tools). However, the possibility cannot be excluded that the stress associated with water shift in the aquaria could affect the fish and thereby influence cell density. This effect would evidently be of far lesser importance than infection.

It has been proposed that these putative mast cells correspond to eosinophilic granular cells which appear in formalin-fixed tissue stained with, e.g., Giemsa (Reite 1998). These cells have been found in Salmo trutta (Blackston \& Pickering 1980), and recently Matsuyama \& Iida (1999) provided evidence for involvement of these cells in inflammatory reactions in tilapia. The latter authors described degranulation of eosinophilic granular cells in swim bladders and peritoneum following injection with bacteria. These cells have been known to occur in salmonid tissue, where they respond to various bacterial products (Ellis 1985, Vallejo \& Ellis 1989, Powell et al. 1993, Reite \& Evensen 1994). In addition, the present work shows that thionin-postive cells occur in brown trout fin epidermis, where they seem to degranulate upon infection with skin parasites. Therefore, the possibility cannot be excluded that these cells have some mast-cell-like functions.

Nothing is known about regeneration of piscine mast cells upon such an activation, but evidently recruitment of thionin-positive cells to the epidermis is a process which takes more than $9 \mathrm{~d}$ under the conditions described. This points to a difference between some mammalian mast cell types and the putative piscine mast cells. Following degranulation of mucosal mast cells in sheep, those cells will in some cases increase in number in the affected tissue within a few days (Harrison et al. 1999). In this context it should be emphasized that it is unlikely that thionin-positive teleost cells are fully identical to mammalian mast cells and they may accordingly act differently at least in some respects. In addition, the lower temperature (compared to mammalian body temperature) at which fish normally live could also play a role in the kinetics of this teleost cell type. In other respects as well one may find significant differences. Mast cells play a prominent role in mammals responding to parasite infections (Galli et al. 1999, Harrison et al. 1999, Meeusen 1999) with degranulation of these cells due to specific interaction between antigen and IgE on the cell membrane. However, as the immunoglobulin class IgE does not occur in teleosts, the possibility can be excluded that such antibodies attach to the surface membrane of mast cells in fish and elicit mediator release following antigen cross-binding. Despite these differences some important mechanisms in innate immunity associated with the putative mast cells could occur in teleosts. The thionin-positive cells in both swim bladder walls and trout fins are superficially located and are likely to be in close contact with any pertubation in the environment. Therefore, they could be induced to release their cytoplasmic granules upon any contact of a mechanical, physical or chemical kind. This non-specific but pro-inflammatory reaction could contribute to a primary response and activation of subsequent reaction of both specific and non-specific elements of the host's immune system. In this context it should be noted that the corneae were devoid of mast cells in both uninfected and infected trout. Previous investigations have pointed to the corneae as immunoprivileged sites in trout (Buchmann \& Bresciani 1998). Thus, the corneal epithelium is devoid of mucous cells and according to the present investigation also putative mast cells. The cornea seems to offer a less hostile microenvironment for ectoparasites such as Gyrodactylus derjavini when the skin of the host responds and elicits a decrease in parasite numbers. This further suggests that teleost mast cells play a role in antiparasitic host responses.

Acknowledgements. This study was supported by the Danish Ministry of Food, Agriculture and Fisheries (FISK97-3).

\section{LITERATURE CITED}

Blackstock N, Pickering AD (1980) Acidophilic granular cells in the epidermis of the brown trout, Salmo trutta L. Cell Tissue Res 210:359-369

Buchmann $\mathrm{K}$ (1999) Immune mechanisms in fish skin against monogeneans - a model. Folia Parasitol 46:1-9

Buchmann K, Bresciani J (1998) Microenvironment of Gyrodactylus derjavini on rainbow trout Oncorhynchus mykiss: association between mucous cell density in skin and site selection. Parasitol Res 84:17-24

Buchmann K, Lindenstrøm T, Sigh J (1999) Partial crossprotection against Ichthyophthirius multifiliis infection in Gyrodactylus derjavini immunized rainbow trout. J Helminthol 73:189-195

Bullock WL (1963) Intestinal histology of some salmonid fishes with particular reference to the histopathology of acanthocephalan infections. J Morphol 112:23-43

Clark TG, Dickerson HW (1997) Antibody-mediated effects on parasite behavior: evidence of a novel mechanism of immunity against a parasitic protist. Parasitol Today 13: $477-480$

Ellis AE (1985) Eosinophilic granular cells (EGC) and histamine responses to Aeromonas salmonicida toxins in rainbow trout. Dev Comp Immunol 9:251-260

Galli SJ, Maurer M, Lantz CS (1999) Mast cells as sentinels of innate immunity. Curr Opin Immunol 11:53-59

Harrison GBL, Pulford HD, Gatehouse TK, Shaw RJ, Pfeffer 
A, Shoemaker CB (1999) Studies on the role of mucus and mucosal hypersensitivity reactions during rejection of Trichostrongylus colubriformis from the intestine of immune sheep using an experimental challenge model. Int J Parasitol 29:459-468

Matsuyama T, Iida I (1999) Degranulation of eosinophilic granular cells with possible involvement in neutrophil migration to site of inflammation in tilapia. Dev Comp Immunol 23:451-457

Meeusen ENT (1999) Immunology of helminth infections, with special reference to immunopathology. Vet Parasitol $84: 259-273$

Powell MD, Briand HA, Wright GM, Burka JF (1993) Rainbow trout (Oncorhynchus mykiss Walbaum) intestinal eosinophilic granule cell (ECG) response to Aeromonas salmoni-

Editorial responsibility: Wolfgang Körting,

Hannover, Germany cida and Vibrio anguillarum extracellular products. Fish Shellfish Immunol 3:279-289

Reite OB (1998) Mast cells/eosinophilic granule cells of teleostean fish: a review focusing on staining properties and functional responses. Fish Shellfish Immunol 8: $489-513$

Reite $O B$, Evensen $\varnothing$ (1994) Mast cells in the swimbladder of Atlantic salmon Salmo salar: histochemistry and responses to compound $48 / 80$ and formalin-inactivated Aeromonas salmonicida. Dis Aquat Org 20:95-100

Vallejo AN, Ellis AE (1989) Ultrastructural study of the response of eosinophil granule cells to Aeromonas salmonicida extracellular products and histamine liberators in rainbow trout, Salmo gairdneri Richardson. Dev Comp Immunol 13:133-148

Submitted: August 30, 1999; Accepted: February 29, 2000 Proofs received from author(s): May 29, 2000 